\title{
Alliances and Competitive Advantage
}

\author{
Popescu Doina, Ceptureanu Sebastian, and Ceptureanu Eduard
}

\begin{abstract}
Alliances can help firms to achieve their objectives in several ways. Alliances not only spread the risk of business ventures by sharing that risk with other firms, they also give firms access to knowledge, resources, and capabilities that the firm might otherwise lack. Through alliances potential competitive advantage is achieved in four ways: joint investment, knowledge sharing, complementary resources, and effective management.
\end{abstract}

Index Terms-Alliance, competitive advantage, knowledge sharing.

\section{INTRODUCTION}

\section{A. Joint Investments}

Regarding joint investment, alliances can help to increase returns by motivating firms to make investments that they would be unwilling to make outside a formal alliance relationship. This advantage is particularly important in light of the fact that productivity gains are possible when activities linked in the value chain are supported with transaction-specific investments.

In many situations, a supplier won't make an investment pertaining specifically to an exchange with one buyer. The reason is that the investment would tie the supplier too closely to one buyer and expose it to too much risk, the greatest risk being that the buyer would not buy the supplier's products or services, and also grinds the supplier down on price due to its dependence on the single buyer. The supplier`s hesitancy, however, can be overcome if the buyer is willing to enter a formal arrangement that reduces the supplier`s risk.

\section{1) Knowledge sharing}

Regarding knowledge sharing, one common reason of entering into alliances is to learn from partners. Learning, however, requires partners to cooperate in transferring knowledge. Although partners may not be equally capable of absorbing knowledge, two factors can help to facilitate the transfer of knowledge:

1) mutual trust and familiarity between partners;

2) consistent information-sharing routines, such as that obtained through higher - level executive contact, integrated information systems, and employee swapping and cross-company career paths [1].

Manuscript received June 13, 2012; revised August 19, 2012.This work was supported in part by the Romanian Government under Grant PN2 Idei $1470 / 2008$.

The authors are with the Bucharest University of Economic Studies, Romana Square 6, Romania (e-mail: doinaipopescu@yahoo.com, ceptureanu@yahoo.com, eduard_ceptureanu@yahoo.com).

\section{2) Complementary resources}

In accordance with knowledge sharing are complementary resources. Thus, the firm`s resources and capabilities are the primary sources of competitive advantage. In this vein, when partners combine resources and capabilities they may be able to create a stock of resources that's unavailable to other competitors. If that stock combines complementary resources and capabilities, then the alliance may be able to generate a shared advantage. If the combination of resources and capabilities is valuable and rare, the alliance may be able to generate greater profits than the sum of the partners individual profits [2].

\section{B. Effective Management}

Regarding effective management, a way to judge whether an alliance is effective is if it helps build a competitive advantage.

It is known that resources and capabilities are the basis of competitive advantage only when they satisfy certain criteria: they must be valuable, rare, difficult to imitate, and supported by organizational arrangements. If an alliance (or network of alliances) is a vehicle that helps the firm`s strategy satisfy these criteria, it has probably developed a collaborative advantage that helps one or more of the member firms achieve a competitive advantage over rivals outside the alliance [3].

\section{1) Clusters}

Successful businesses are conditioned by easy and fast access to knowledge, highly qualified workforce, specialized technical and social assistance, and by quick identification of suppliers, customers and innovative solutions. These requirements can be most easily achieved through clusters.

The most successful clusters have been created spontaneously, as a result of natural competitive advantages, of market forces or simply of chance [4].

The cluster has become an important element of innovation policies in the Member States of the European Union [5]. The European Union supports an approach based on regional innovative clusters in urban centres not only developed but also in poorer or rural regions [6]. European Cluster Observatory has identified about 2000 clusters, supported by policies and concrete projects of national and European funding. Since 2006, the European Commission identified the development of innovative clusters as one of the strategic priorities for the successful promotion of innovation. Innovative clusters are polarized around innovative companies (including start-ups and spin-offs) and around research organizations which have the role of stimulating innovation in companies through intensive interaction to promote research results, exchange facilities, experience and knowledge and technology transfer through concrete activities. 
Europe does not lack clusters, but market fragmentation, weak linkages between research and industry and insufficient cooperation within EU have led to the lack of a necessary critical mass within European clusters and of innovation capabilities to face global competition and leading to higher level clusters.

\section{2) Romanian Clusters}

In Romania, for example, clusters are in an early stage, compared with other EU countries, but may have already noticed some initiatives in this area. [7]. In Western Romania there is a high potential for cluster formation and already exist forms of cooperation and interacting. Thus, under the aegis of the West Regional Development Agency was created an innovative network "Tehimpuls" which brings together all regional actors involved in innovation and were taken the first steps in creating a cluster in the automotive sector, near the Dacia Group Renault Romania Company. Business Incubator and Technology Transfer Centre at the „Polytechnic" University of Timisoara formed the nucleus of a cluster. Also, in Covasna county exist an innovator cluster in wood processing, financial sustained effort being by the EU within Framework Programme 7, the "PROWOOD" [8].

Also, there were organized 24 seminars (including eight with the support of GTZ Germany - Gesellschaft für Technische Zusammenarbeit) in all regions with economical potential of the country in order to implement in Romania the concept of innovative clusters, identify existing and emerging clusters and elaboration of a Romanian Cluster Mapping.

In the textile-garment field there are two clusters, in various forms of development, both situated on North- East of the country. The first of them, ASTRICO North East was formed and organized around the main producers of yarn, knitwear, fabrics from north-east of the country, plus the Regional Development Agency North-East and The "Gheorghe Asachi" Technical University of Iasi [9].

Within ASTRICO cluster, given the large reduction in lohn orders (large orders with delivery within more than six weeks for which are preferred other countries), Romanian clothing firms have substantially reduced production capacity to accommodate to smaller orders that are majority placed further in Romania. This cluster has been created to strengthen cooperation between these producers in order to meet large orders which still exist (about 3-4 months / year), but with delivery times of up to six weeks. Thus, one single manufacturer has not capacity to execute such orders and respecting these terms. Also, another major advantage of this cluster is that one of the firms of cluster is the one that providing raw materials for others. In addition, for clusters formations are specific lines of financing, the financial part of the grant is over $50 \%$ as minimum and almost $98 \%$ for structural funds SOP HRD.

Michael Porter claims that clusters have the potential to affect competition in three ways [10]:
1) by increasing the productivity of the companies in the cluster;

2) by driving innovation in the field;

3) by stimulating new businesses in the field.

Unfortunately, Romanian clusters, specifically in the textile-clothing field, for example, still do not meet the exact role of a cluster and which is to increase the productivity with which companies can compete nationally and globally. Thus, there is no interconnection of business at sharing of resources level such as knowledge management.

Also, this one it is not a supply chain cluster (system of organizations, people, technology, activities, information and resources involved in moving a product or service from supplier to costumer). The cooperation consist in fact that (1) there is a company which provide raw materials and (2) exist collaboration between the producers in order to meet large orders because one single manufacturer would not have capacity to execute such orders and capacity to respect the delivery terms.

At this time, actions within this cluster represent rather a short-term response to fluctuating demands of the market and transient. With time, clusters from Romania will have to react after cluster principles, focusing on research, innovation and development of long-term strategy [11].

\section{ACKNOWLEDGMENT}

The authors thank Romanian Government for financing PN2 Idei 1470/2008 project.

\section{REFERENCES}

[1] M. A. Carpenter and W. G. Sanders, Strategic Management-A Dynamic Perspective; Concepts and Cases, 2nd Ed., New Jersey, U.S.: Pearson Prentice Hall, , pp. 322, 2009.

[2] M. Motta, Competition Policy. Theory and Practice, Cambridge: Cambridge University Press, pp. 99, 2004.

[3] T. Gavrila and D. Popescu, Euromarkeing-Strategiile firmei, Ed. ERA, Bucuresti, pp. 64, 2001.

[4] M. E. Porter, The Competitive Advantage of Nations, New York: Free Press, pp. 42, 1998.

[5] O. Moen, "The Born Globals: A New Generation of Small European Exporters," International Marketing Review, pp. 58, 2002.

[6] I. Gavrila, T. Gavrila, and A. Popescu, Mediul concurential si politica Uniunii Europene in domeniul concurentei, Ed. Economica, Bucuresti, pp. $65,2006$.

[7] S. Ceptureanu, "Knowledge management model for Romanian companies," Revista de Management Comparat International, vol. 10 no. 1, 2009, pp. 15, 2009.

[8] O. Nicolescu and S. Ceptureanu, "Romania's integration in the European Union and the absorption of structural funds," Revista Economia. Seria Management, The Proceedings of the ninth International Conference Investments and Economic Recovery (Part II), Bucharest, vol.12, no. 2, pp. 37, may 22-23, 2009.

[9] A. Turp and Balazs, "Clusterul ASTRICO Nord/Est Toti pentru unu," Dialog textil, no.3, pp. 12, 2010.

[10] M. E. Porter, "Clusters and the new economics of competition," Harvard Business Review, vol. 76, no. 6, pp.77, Nov. Dec. 1998.

[11] I. Popa, Management strategic, Ed. Economica, Bucuresti, pp.35, 2004. 